\title{
Gerakan Zero Waste Sebagai Bentuk Peduli Pada Lingkungan Hidup di Kota Tangerang Selatan
}

\section{Dewi Rahayu'}

Ilmu Pemerintahan, FISIP Universitas Sultan Ageng Tirtayasa dewirahayu1009@gmail.com

\section{Abdul Riyansah ${ }^{2}$}

Ilmu Pemerintahan, FISIP Universitas Sultan Ageng Tirtayasa abdulriyansah11@gmail.com

\section{Dewi Sri Astuti ${ }^{3}$}

Ilmu Pemerintahan, FISIP Universitas Sultan Ageng Tirtayasa dewielfina7@gmail.com

\section{Faidurrizal ${ }^{4}$}

Ilmu Pemerintahan, FISIP Universitas Sultan Ageng Tirtayasa faidurrizal.izal25@gmail.com

\section{E-ISSN 2721-0642}

\section{Article Info}

Recieved:

June 292021

Revised:

July 212021

Accepted:

July 312021

Doi Number

https://doi.org/10.37950/ijd.v3i2.98

\begin{abstract}
Zero waste is a movement that cares about the environment by reducing waste or not producing waste, which in turn can reduce demand. Garbage will be a threat to the health of living things to the planet earth. The purpose of this study is to be able to see and know the zero waste movement as a form of caring for the environment in South Tangerang City, as well as to increase public awareness in maintaining ecological balance through active participation. In analyzing, the author uses the theory of environmental politics with environmentalism and uses a qualitative research method approach and descriptive type. Then the data collection techniques are carried out through library research or literature studies and direct observation and interviews. How to analyze the data is done by reducing the data, presenting the data and drawing conclusions. So that the analysis of the zero waste movement will produce a result by showing the Minim Waste House program, which is a support program for communities that care about the environment and have an online environmental movement base through social media, one of which is by campaigning for a lifestyle by inviting the community and offline by implementing direct movements such as providing education regarding the importance of waste management as well as the garbage bin movement which is a waste clean action in South Tangerang City. The Minimized Waste House Program collaborates with the South Tangerang City Environmental Service (DLH) regarding its implementation, so far its implementation has been running but it is still not fully optimal because it is influenced by several factors such as inadequate infrastructure and public awareness which is quite lacking in its management.
\end{abstract}

Keywords: Social Movement, Zero waste Movement, Garbage in South Tangerang City. 


\begin{abstract}
Abstrak
Zero waste menjadi salah satu gerakan yang peduli terhadap lingkungan hidup dengan mengurangi sampah atau tidak menghasilkan sampah, yang pada akhirnya dapat mengurangi kebutuhan. Sampah akan menjadi sebuah ancaman bagi kesehatan makhluk hidup hingga planet bumi. Tujuan dalam penelitian ini untuk dapat melihat serta mengetahui gerakan zero waste sebagai bentuk peduli terhadap lingkungan hidup di Kota Tangerang Selatan, serta sebagai peningkatan kesadaran masyarakat dalam menjaga keseimbangan ekologis melalui partisipasi aktif. Dalam menganalisis, penulis menggunakan teori politik lingkungan dengan enviromentalisme serta menggunakan pendekatan metode penelitian kualitatif dan jenis deskriptif. Lalu dalam teknik pengumpulan data dilakukan melalui studi kepustakaan atau studi literature dan observasi secara langsung serta wawancara. Cara menganalisis data yang dilakukan dengan mereduksi data, menyajikan data dan menarik kesimpulan. Sehingga analisis gerakan zero waste akan menghasilkan sebuah hasil dengan menunjukan program Rumah Minim Sampah, yang menjadi program pendukung dari komunitas yang peduli terhadap lingkungan dan mempunyai basis gerakan lingkungan secara online melalui media sosial salah satunya dengan mengkampanyekan gaya hidup dengan mengajak masyarakat dan secara offline dengan penerapan gerakan secara langsung seperti memberikan edukasi terkait pentingnya pengelolaan sampah serta gerakan bak sampah yang menjadi aksi bersih sampah di Kota Tangerang Selatan. Program Rumah Minim Sampah berkolaborasi dengan Dinas Lingkungan Hidup (DLH) Kota Tanggerang Selatan terkait dengan pelaksanaannya, sejauh ini pelaksanaanya telah berjalan namun masih belum terbilang belum sepenuhnya optimal karena dipengaruhi oleh beberapa faktor seperti sarana prasarana kurang memadai serta kesadaran masyarakat yang terbilang cukup kurang dalam pengelolaannya.
\end{abstract}

Kata Kunci: Gerakan Sosial, Gerakan zero waste, Sampah di Kota Tangerang Selatan

\title{
Pendahuluan
}

Gerakan sosial (social movement) memiliki peran penting pada tindakan yang sifatnya kolektif (collective behavior). Tindakan kolektif dipahami dengan suatu kesatuan yang memiliki tujuan guna meningkatkan pengaruh dan kekuasaan dari beberapa kelompok dengan adanya kepentingan umum. Maka gerakan sosial menjadi aktivitas yang teorganisir dalam mendorong atau menghambat suatu tujuan terkait perubahan sosial. Sejalan dengan gagasan Locher, ketika beberapa kelompok yang memiliki kekuasaan mengatur jalannya suatu tindakan artinya sedang memperjuangkan dalam menciptakan sebuah gerakan sosial guna adanya suatu perubahan sosial (Locher, 2002). Peristiwa gerakan sosial yang terjadi memiliki sifat dinamis dan mempunyai misi tertentu yaitu perubahan yang lebih baik dalam mengatasi sebuah permasalahan. Sehingga lahirnya gerakan sosial dimulai dari rasa kekecewaan mengenai isu tertentu dan merugikan suatu kelompok. Sehingga memunculkan suatu gerakan yang memiliki 
orientasi terhadap isu lingkungan yang dirasa perlu diperhatikan karena dampaknya akan mengancam berbagai sektor kehidupan serta menghambat keberlanjutan pada proses lingkungan.

Isu lingkungan dalam hal ini tidak terlepas dari persoalan sampah yang kian hari kian meningkat. Permasalahan sampah menjadi suatu topik yang seringkali dibicarakan pada kota-kota besar dan menjadi sumber pencemaran pada lingkungan. Salah satu permasalahan sampah yang dalam hal ini yaitu pada Kota Tangerang Selatan atau bisa disingkat Tangsel. Tangsel menjadi salah satu kota dengan jumlah penduduk yang cukup banyak dan pemukiman yang cukup padat penduduknya. Dimana hal tersebut menimbulkan pada persoalan sampah yang terus meningkat di Kota Tangerang Selatan. Mengutip dari data Bappeda Kota Tangerang Selatan, jumlah penduduk telah mencapai 1.492.999 jiwa yang terbilang meningkat sebanyak 3,44\% (Bappeda Kota Tangerang Selatan). Adapun faktor peningkatan jumlah sampah salah satunya diakibatkan dengan peningkatan jumlah penduduk yang secara tidak langsung dapat menghasilkan peningkatan terhadap pola hidup yang dijalankan.

Sampah di Kota Tangerang Selatan yang paling dominan yaitu sampah pelastik. Dimana sampah plastik termasuk bahan anorganik yang sangat membutuhkan banyak waktu dalam menguraikan serta meningkatkan jumlah limbah yang diperoleh. Sehingga munculnya sebuah inisiatif pada gerakan sosial yang dilakukan oleh masyarakat sebagai perbaikan sebuah kualitas lingkungan dimulai dari gaya hidup yang berubah. Sebetulnya Pemerintah memiliki tanggung jawab lebih atas perlindungan lingkungan hidup karena memiliki kepentingan dalam pembuatan regulasi serta pengawasan, sehingga menjadi harapan besar bagi masyarakat untuk pihak pemerintah dapat menjalankan sesuai dengan fungsi dari peraturan yang telah ditegakkan.

Faktor penting berasal dari degradasi lingkungan terkait kultur masyarakat yang cenderung apatis mengenai keberlangsungan lingkungan. Sesuai dengan kegiatan pertemuan internasional "The Power of Culture in Sustainable" yang digelar oleh pihak Indonesia dalam membangun suatu kesadaran masyarakat mengenai pentingnya sebuah prinsip pemenuhan kebutuhan saat ini dengan tidak mengorbankan kebutuhan bagi generasi masa depan. Masyarakat yang terlibat menjadi sebuah modal sosial dalam kehidupan bermasyarakat sebagai faktor pendorong dalam menjalankan tindakan bersama dengan satu tujuan yang telah ditentukan. Tindakan yang dilakukan secara kolektif menuntut adanya pengembangan masyarakat yang secara terorganisir dapat meningkatkan suatu potensi yang dimiliki oleh masyarakat secara mandiri dan integrasi.

Maka berdasarkan hal tersebut menarik untuk meloihat suatu persoalan tersebut dalam sudut pandang sebagai suatu gerakan zero waste. Maka untuk itu penulis mencoba memberikan suatu batasan dalam pembahasan yang nantinya penulis lakukan kepada suatu gerkan zero waste yang dipahami sebagai konsep dalam pengelolaan sampah secara bersama dengan menerapkan tiga prinsip yaitu reduce, russe, dan recyle. Urgensinya sebagai support masyarakat dalam merubah pola hidupnya dengan memanfaatkan sumber daya yang dapat di produksi kembali. Sehingga zero waste menjadi kampanye dalam upaya mengurangi plastik yang hanya sekali pakai (single use plastic) sebagai 
gerakan dalam mengevaluasi masyarakat pada gaya hidup yang dilakukan saat ini yang membawa dampak negatif terhadap lingkungan dan membutuhkan dukungan oleh seluruh kalangan masyarakat sebagai gerakan sosial. Melalui Program Minim Sampah menjadi salah satu kajian di dalam karya ilmiah dalam melihat seberapa efektifkah kerjasama yang dilakukan oleh pihak Pemerintah, komunitas, dan masyarakat dalam mengatasi persoalan sampah. Gerakan Zero waste merupakan sebuah gerakan dalam hal lingkungan yang memiliki tujuan mengajak masyarakat menjalani gaya hidup dengan meminimalisir produksi sampah yang jatuh ke Tempat Pembuangan sampah Akhir (TPA) sebagai upaya menjaga lingkungan.

Telah lama Kota Tangerang Selatan mempunyai suatu permasalahan mengenai TPA. Terjadinya penjebolan TPA yang terletak di Kecamatan Serpong dan dikelola oleh DLH Tangsel yang mengakibatkan penumpukan limbah atas timbunan sampah yang longsor ke dalam sungai. Lahan yang digunakan sebagai TPA tidak diperbolehkan oleh pemiliknya sehingga sudah tidak dapat lagi menampung sampah 1.200ton sehari dikarenakan lahan yang sangat terbatas. Selain itu lahannya dibangun disekitar rumah penduduk yang otomatis membawa dampak terhadap kesehatan masyarakat karena bau yang tidak sedapnya. Maka untuk mengatasi persoalan tersebut ada beberapa pihak yang terlibat dalam upaya melakukan gerakan zero waste, yaitu diantaranya ada masyarakat, pemerintah, dan komunitas-komunitas lingkungan yang salah satunya adalah Lab Tanya. Pihak-pihak terkait inilah yang nantinya akan menjalankan dan mensosialisasikan gerakan zero waste kepada masyarakat secara luas di Kota Tangerang Selatan.

Lebih lanjut, Lab Tanya menjadi salah satu komunitas atau penggerak yang hadir untuk menjalankan visi misinya dalam permasalahan sampah dibeberapa kota termasuk Tangerang Selatan. LabTanya mempunyai slogan "Kota Tanpa Sampah" yang di mana terbetuk diakhir tahun 2014 dengan tujuan sebagai alat produksi pengetahuan dan transformasi sosial ekologis. LabTanya merupakan komunitas independent dan bukan NGO. Pada tahun 2015 LabTanya mencetuskan program Rumah Minim Sampah pada tahun 2015 dengan menawarkan strategi tiga pintu (depan, tengah, belakang). Dalam perjalanannya, program tersebut mendapat respon positif dari masyarakat dan juga Pemerintah serta ditawarkan dan akan diadopsi menjadi program unggulan lembaga atau instansi terkait di Tangerang Selatan. Dalam hal ini membuktikan bahwa Pemerintah tidak lagi menjadi kekuataan tunggal dalam menentukan suatu kebijakan mengenai lingkungan hidup. Berdasarkan permasalahan yang sudah disebutkan, maka penulis mencoba memunculkan pertanyaan secara umum sebagai bentuk batasan dalam tulisan ini yaitu bagaimana dinamika suatu gerakan zero waste di Kota Tangerang Selatan sebagai upaya pihak-pihak terkait dalam mewujudkan kesadaran masyarakat dalam merubah pola pikir kearah bijaksana terhadap persoalan sampah dan pelestarian lingkungan hidup di masyarakat Kota Tangerang selatan. 


\section{Kerangka Teori}

\section{Collaborative Governance}

Collaborative Governance merupakan sebuah konsep sebagai acuan atas upaya bersama dari pemangku kepentingan dan non-state untuk bekerjasama dalam mengatasi permasalahan yang kompleks melalui pengambilan keputusan secara kolektif dan implementasi. Collaborative governance mendorong untuk menyoroti bagaimana kepentingan, kekuatan, dan kelemahan yang berbeda terlibat satu sama lain dalam mecapai tujuan bersama. Menurut Islamy (2018:2) Collaborative governance menjadi sebuah kontrol antara satu dengan lembaga publik lainnya yang melibatkan berbagai komponen stakeholders non-state dalam mengambil sebuah keputusan yang sifatnya formal demi kepentingan kolektif, dan memiliki orientasi konsensus serta deliberatif yang memiliki sebuah tujuan dalam membuat serta menerapkan program publik yang menjadi sebuah kebijakan. Beberapa ahli telah menempatkan collaborative governance pada tahap implementasi. Di mana Ansell dan Gash (dalam Islamy, 2018) memandang collaborative governance ini sebagai esensi Pemerintahan kolaboratif dalam membuat keputusan kolektif. Artinya, dalam collaborative governance bukan hanya Pemerintah saja yang mengambil peran dalam merumuskan keputusan dan kebijakan publik, bukan pula hanya menggabungkan antara masyarakat dengan lembaga non-state lain untuk menjadi penonton dalam pengambilan keputusan, tetapi collaborative governance dikonseptualisasikan sebagai jenis Pemerintahan yang mencakup fitur demokrasi deliberatif dengan menggunakan pendekatan dialog dan pengambilan keputusan antar pemangku kepentingan dengan basis konsensus.

Dengan menerapkan teori collaborative governance, diharap mampu menarik pola yang seimbang untuk sama-sama mencari solusi dan menyelesaikan permasalahan yang kompleks secara efektif. Untuk dapat mengelola sumber daya dan keseimbangan kekuatan, maka Pemerintah tidak akan bisa bergerak sendiri tanpa keterlibatan peran dari lembaga lain dan juga masyarakat, berbagai elemen dan pemangku kepentingan yang memiliki tujuan yang sama dengan memiliki saling ketergatungan demi tujuan kolektifnya.

\section{Environmentalisme}

Enviromentalisme termasuk ke dalam suatu gerakan sosial yang memiliki pelopor sebagai perlingdungan lingkungan hidup. Gerakan yang dilakukan tidak menggunakan cara kekerasan, yang dimulai dari turunnya aksi ke jalan, memberikan sebuah edukasi kepublik terkait perlindungan ekosistem maupun lingkungan, sampai dengan melaksanakan lobi politik. Perspektif environmentalisme didasari oleh adanya green movement, di mana green movement ini memberikan kesadaran terkait dampak buruk bagi lingkungan yang dikarenakan dengan perkembangan sebuah peradaban manusia. Salah satunya terdapat sebuah fakta terkait kasus krisis lingkungan yang dialami oleh masyarakat. Maka dari itu, kaum environmentalisme mengakui struktur yang ada, serta inisiatif bergerak dalam menyelemati lingkungan dan membawa isu-isu terkait perhatian lingkungan. 
Terdapat tiga konsep yang menjadi komponen utama environmentalisme, yaitu : 1) Konsep environmentalisme mempunyai keterkaitan antara alam dengan manusia, sehingga dapat menguraikan bagaimana hubungan dari alam dengan perilaku manusia yang sebenarnya terkait hubungan perilaku harmonis menganggu suatu keseimbangan. 2) Konsep environmentalisme mempunyai keterkaitan dengan ideologi alam dan perjuangan. Ideologi menjadi bentuk doktrin, terkait apa yang diyakini setiap individu maupun kelompok yang akan dijadikan dasar dalam melakukan sesuatu. Sedangkan perjuangan dengan ideologi alam mencoba menguraikan implementasi dari sebuah pola ide ataupun gagasan masyarakat yang menjadi suatu perilaku sosialnya. 3) Konsep environmentalisme mempunyai keterkaitan erat dengan perancangan pengamanan alam sekitar. Artinya, environmentalisme juga beranggapan bahwa pihak yang memiliki kewenangan mempunyai peran untuk terlibat dengan asas idealisme dalam menyelenggarakan di berbagai aspek.

Penggunakan teori ini akan mampu menjelaskan bagaimana gerakan lingkungan dalam konsep zero waste mempunyai visi untuk menyelamatkan Kota Tangerang Selatan khususnya dari krisis lingkungan. Gerakan ini diwujudkan dalam bentuk gerakan lingkungan menggunakan konsep zero waste yang dilakukan oleh komunitas, masyarakat dan juga Pemerintah. Di mana elemen-elemen ini mempunyai peranan masing-masing dalam manangani persoalan sampah yang berada di Kota Tangerang Selatan. Gerakan zero waste tersebut sesuai dengan teori dan aspek dari sebuah gerakan enviromentalisme.

\section{Metode Penelitian}

Penggunaan kualitatif yang penulis pilih pada metode penelitian ini. Metode penelitian menjadi hal utama untuk dapat menghasilkan serta menyajikan deskripsi data melalui beberapa hal yang dapat dari perilaku orang-orang yang menjadi objek dalam bentuk tertulis maupun lisan (Moleong, 2011). Dimana dalam penelitian ini dilakukan pada sebuah objek dan tidak adanya pengaruh seorang penulis dalam dinamika yang terjadi pada setiap objek, akan tetapi penulis hanya menganalisis dari kejadian yang dilakukan serta memotret lalu mengkonstruksikan terkait keadaan sosial yang terjadi yang akan menjadi sebuah aspek yang lebih bermakna sekaligus jelas dalam memahaminya (Sugiyono, 2012). Dengan menggunakan metode kualitatif, sehingga penulis nantinya dapat melakukan analisis terkait fenomena yang terjadi dan menghubungkannya dengan teori-teori yang relevan.

Selain itu, untuk mendapatkan data penelitian, penulis menggunakan studi wawancara, observasi, dan studi kepustakaan atau studi literature dalam mengumpulan sebuah data-data yang didapatkan. Dimana penulis melakukan wawancara kepada narasumber terkait yang berhubungan dengan gerakan zero waste ini, diantaranya seperti Dinas Lingkungan Hidup dan penanggungjawab Program Rumah Minim Sampah. Selain itu juga penulis melakukan observasi, dimana penulis terjun langsung ke lokasi pemukiman masyarakat dan tempat Pembuangan Sampah Akhir (TPA Cipeucang) yang berada di Kecamatan Serpong, Kota Tangerang Selatan. Dan penulis juga melakukan 
studi kepustakaan, dimana dalam hal ini penulis mencari dokumen-dokumen atau sumber-sumber data yang berasal dari buku, jurnal ilmiah, internet, dan sumber data lainnya. Sumber data tersebut dapat dikatakan sebagai sumber data sekunder.

Lebih lanjut, dalam penelitian ini juga membedah dari sudut pandang studi kasus. Dimana studi kasusnya berupa program dan gerakan yang dilakukan oleh Pemerintah dan masyarakat dalam upaya mengurangi sampah (zero waste), dengan tujuan agar penelitian dapat fokus pada inti permasalahan. Dimana studi kasus memiliki kegunaan dalam memahami masalah dan menjadi teknik analisis dalam melihat kasus yang didapatkan lalu disajikan menjadi suatu pandangan penulis sebagai subjek. Dari konsep yang disebutkan diatas diharapkan mampu menggali data yang akurat dalam penelitian ini dan dapat dianalisis dengan baik. Maka berdasarkan hal tersebut, penulis menganggap metode penelitian kualitatif inilah yang cocok untuk meneliti fenomena dari gerakan lingkungan atau "zero waste" sebagai bentuk keperdulian manusia terhadap lingkungan, tertutama di Kota Tangerang Selatan.

\section{Hasil dan Diskusi}

Kota Tangerang Selatan menghasilkan volume sampah perharinya sekitar 9801000 ton/hari sedangkan TPA Cipeucang hanya dapat menampung sekitar 400 ton/hari sehingga adanya kerjasama antara pihak Pemerintah, swasta, dan komunitas yang menjadi nilai positif. Mengacu pada PERDA No. 3 Tahun 2013 tentang Pengelolaan Sampah bahwa masyarakat memiliki kewajiban dalam menjaga lingkungan hidup. Sampah diartikan menjadi sebuah benda atau barang yang tidak memiliki manfaatnya, dari hal tersebut dapat memunculkan pemahaman negatif yang harus disingkirkan. Oleh sebab itu, paradigma terkait pemahaman sampah perlu dirubah terlebih dahulu agar meningkatkan kesadaran masyarakat dan dapat meminimilisir permasalahan sampah.

Pengelolaan sampah pada generasi selanjutnya lebih menitikberatkan pada cara pandang dan perilaku masyarakat. Oleh karena itu, perlu adanya perubahan yang dimana keikutsertaan masyarakat dengan pendekatan bottom-up yang dirasa relevan untuk mengawal partisipatif masyarakat, disamping itu pendekatan up-bottom terbukti tidak dijalankan dengan efektif sehingga tidak mendapatkan dampak yang signifikan. Berdasarkan data yang diperoleh dari Dinas Lingkungan Hidup (DLH) Kota Tangerang Selatan memperlihatkan suatu peningkatan persentase dalam pengelolaan sampah dari tahun 2018-2020. Persentase sampah terkelola pada tahun 2018 mencapai 62,97\%. Lalu pada tahun 2019 mencapai 71,20\%. Dan pada tahun 2020 mencapai 88,50\%. Kemudian untuk sampah yang terkelola di tahun 2020 sebesar 88,50\% tersebut mencakup 61,06\% nya ditangani oleh DLH Kota Tangerang Selatan. 11,56\% pengurangan oleh masyarakat. Serta 15,8\% ditangani oleh pihak swasta. Dari data tersebut bisa ditarik sebuah kesimpulan bahwa dari tahun ke tahun pengelolaan sampah tersebut berjalan efektif dengan kolaborasi antara Pemerintah, masyarakat dan swasta. Sehingga gerakan zero waste ini mempunyai harapan untuk terus menjalankan misi dan mewujudkan visi dalam masalah krisis lingkungan di Kota Tangerang Selatan. 


\section{Program Rumah Minim Sampah Sebagai Gerakan Zero Waste}

Melihat persoalan sampah saat ini menjadi sebuah persoalan yang harus menjadi perhatian umum. Dalam lingkup terkecil seperti tingkat rumah tangga persoalan sampah ini harus diatasi dengan serius. Jika di dalam tingkat rumah tangga sampah bisa dikurangi dan diatasi maka akan mempengaruhi volume sampah yang akan berkurang saat dibuang ke Tempat Pembuangan Akhir (TPA). Hal ini menjadi sebuah latar belakang hadirnya gagasan program Rumah Minim Sampah yang di implementasikan di Kota Tangerang Selatan sebagai wujud gerakan zero waste yang dikampanyekan kepada masyarakat untuk dapat mengedukasi, mengurangi dan mengelola sampah.

Inisiatif program Rumah Minim Sampah yang dinaungi oleh LabTanya sebagai sebuah komunitas berangkat dari adanya tantangan kehidupan dalam masyarakat perkotaan, salah satunya permasalahan sampah yang menjadi tantangan semua pihak untuk mendapatkan hidup yang sehat, nyaman serta ramah lingkungan. Dengan membawa slogan "Kota Tanpa Sampah", LabTanya melakukan eksperimen kepada beberapa komunitas masyarakat sebagai sebuah strategi mengkampanyekan konsep zero waste. Dalam eksperimen tersebut warga dituntut untuk aktif mengembangkan pengetahuan, praktik hidup yang berkesadaran ekologis dan juga minim sampah. LabTanya juga mempunyai modul yang menjadi acuan untuk menjalankan misinya, dalam modul tersebut meliputi bahan eksperimen dan hasil penelitian yang dilakukan LabTanya dengan beberapa komunitas masyarakat sebagai pelopor dari tahun 2015 sampai dengan sekarang sudah ada 23 komunitas masyarakat yang menjadi pelopor gerakan Rumah Minim Sampah yang meliputi Jakarta, Tangerang Selatan dan Banjarmasin.

Eksperimen yang dilakukan LabTanya yaitu dengan menantang komunitas masyarakat untuk melakukan hidup minim sampah selama 7-14 hari. Hasilnya, komunitas masyarakat tersebut mampu untuk mengurangi sampah di rumahnya antara 40\%-98\%, bahkan pada tahun 2020 ada satu keluarga yang mampu mengurangi sampah sampai 99,9\%. Dan sisa-sisa sampah lainnya dijadikan kompos, di daur ulang, dan menjadi residu atau memang harus dibuang ke TPA. Komunitas masyarakat yang menjadi pelopor dalam menjalankan program Rumah Minim Sampah tersebut melakukan strategi tiga pintu dengan teknis memilah sampah atau memisahkan sampah sesuai dengan kategorinya. Yang dilakukan LabTanya pun dengan memperkenalkan strategi Rumah Minim Sampah, mendorong dan berbagi pengetahuan tentang strategi memilih sampah.

Berdasarkan peran LabTanya sebagai 'institusi' penggerak program Rumah Minim Sampah dan komunitas masyarakat sebagai pelopor dalam ekperimen yang telah dilakukan tersebut membuktikan bahwa hal ini menjadi salah satu gerakan zero waste atau pengurangan nol sampah di Kota Tangsel. Dalam eksperimen tersebut membuktikan bahwa ternyata masyarakat mampu untuk mengurangi sampah domestiknya. Hal tersebut perlu menjadi perhatian lebih lanjut dan harus dilakukan secara konsisten dengan tetap menjalin kerjasama dan keterlibatan peran dengan para 
stakeholder dari tingkat Pemerintah Daerah sampai ke level RT/RW untuk melakukan kontroling, monitoring dan evaluasi bersama.

\section{Peran Pemerintah dan Masyarakat Untuk Mengurangi Sampah Sebagai Gerakan Politik Lingkungan}

Gerakan diartikan sebagai aktivitas berupa sebuah tindakan sekelompok orang dalam menanggapi suatu isu tertentu seperti menolak atau mengkampanyekan isu tersebut untuk suatu perubahan. Dalam hal ini, suatu gerakan berkaitan dengan politik lingkungan, dimana hal tersebut memiliki hubungan dalam sebuah tindakannya. Politik lingkungan diartikan sebagai suatu kegiatan politik mengenai Sumber Daya Alam yang dilihat dengan melakukan pendekatan lingkungan hidup. Oleh karena itu, untuk melihat suatu fenomena dalam pembahasan ini maka persepketif lingkungan tentu menjadi hal yang penting. Menurut (Kraft, 2011) politik lingkungan memiliki tiga perspektif diantaranya ekonomi, pengetahuan, dan etika lingkungan. Politik lingkungan diartikan sebagai kajian dibidang ekologi yang dilihat dari suatu akses dan kontrol terhadap sumber daya, dimana hal tersebut tentunya berhubungan dengan keberlanjutan lingkungan. Maka berdasarkan hal tersebut suatu gerakan politik lingkungan menjadi hal yang penting dilakukan ke arah yang baik dan berorientasi pada keberlangsungan di lingkungan hidup kedepan. Maka dengan itu, peran Pemerintah dan masyarakat Kota Tangerang Selatan dalam mengatasi persoalan sampah di wilayah tersebut perlu dilakukan dengan pendekatan politik lingkungan yang baik.

Pemerintah Kota Tangerang Selatan melalui Dinas Lingkungan Hidup memiliki peran penting dalam membuat kebijakan dan program sebagai upaya mengurangi sampah di wilayah Kota Tangerang Selatan. Menurut Dinas Lingkungan Hidup (DLH) Kota Tangerang Selatan, sampah yang dihasilkan perhari mencapai 980-1000 ton/hari sedangkan TPA Cipeucang hanya menampung sekitar 400 ton/hari. Persoalan tersebut menjadi tanggung jawab oleh Pemerintah dan masyarakat Kota Tangerang Selatan. Adapun beberapa tindakan yang diselenggarakan oleh DLH Kota Tangerang Selatan dalam upaya mengurangi sampah, yaitu diantaranya mengeluarkan kebijakan melalui surat edaran Walikota berupa kantong plastik berbayar di toko swalayan dan menggunakan alat makan dan minum pribadi disetiap kantor Pemerintahan. Selain itu, DLH Kota Tangsel juga mengeluarkan beberapa program diantaranya seperti Tempat Pengelolaan Sampah reuse, reduce, recycle (TPS3R) sebanyak 3 buah, membentuk unit-unit Bank Sampah per-RW yang sudah terdapat 313 buah, dan kerja sama dengan pihak swasta. Hal tersebut merupakan gerakan zero waste yang dilakukan oleh Pemerintah melalui DLH Kota Tangerang Selatan sebagai perannya dalam mengurangi sampah.

Selain Pemerintah, masyarakat juga memiliki peran penting dalam mengurangi sampah yang ada di Kota Tangerang Selatan. Dimana masyarakat merupakan subjek dalam memproduksi sampah di kegiatan sehari-harinya, seperti sampah rumah tangga dan sampah pribadi. Sehingga masyarakat juga mempunyai sebuah tanggung jawab penting dalam mengatasi persoalan tersebut. Adapun beberapa tindakan yang dilakukan oleh masyarakat Kota Tangerang Selatan yaitu ikut serta menjadi relawan dalam setiap 
program yang dilakukan oleh DLH Kota Tangsel. Selain itu juga, masyarakat melalui komunitas-komunitas yang bergerak di bidang lingkungan, melakukan upaya pengurangan sampah di Kota Tangerang Selatan. Komunitas masyarakat tersebut, diantaranya Gugus Alam Nalar Ekosistem Pemuda Pemudi (Ganespa), Karang Taruna, Komunitas Tangsel Bersih, Bank Sampah Masyarakat.

Apa yang dilakukan Pemerintah dan masyarakat melalui peranannya, dalam upaya mengurangi sampah merupakan suatu tindakan atau gerakan di bidang lingkungan dengan tujuan melakukan perubahan. Seperti yang disebutkan dalam teori politik lingkungan menurut Schusler dan Krasny dalam (Keraf, 2010) terdapat lima bentuk sebuah tindakan yaitu 1) aksi perbaikan fisik lingkungan, 2) aksi mewujudkan pendidikan lingkungan dengan membentuk sebuah komunitas, 3) aksi nyata dengan melakukan penelitian ilmiah, 4) aksi melakukan analisis dari sebuah isu yang memiliki dampak terhadap lingkungan melalui kebijakan, dan 5) aksi melakukan upaya pengembangan dan pemanfaatan sumber daya menjadi sebuah nilai. Berdasarkan lima hal yang telah diuraikan dihubungan dengan hal-hal yang dilakukan oleh Pemerintah dan masyarakat melalui perannya masing-masing. Pada poin pertama, DLH Kota Tangsel melakukan renovasi dan peningkatan kinerja pada TPA Cipeucang dengan melakukan pembangunan dan penggunaan teknologi sebagai upaya mengurangi sampah. Adapun kondisi fisik menurut pengamatan penulis pada saat melakukan observasi volume sampah yang ada di TPA Cipeucang memang cukup banyak dan sedang ada pembangunan. Lalu poin kedua, terdapat beberapa komunitas yang bergerak di lingkungan hidup melakukan upaya pengurangan sampah melalui pendidikan dan kampanye peduli lingkungan. Dimana hal tersebut dilakukan komunitas melalui media offline dan online seperti pembuatan pamflet, video, dan kampanye di media sosial. Pada poin ketiga, tentu Pemerintah dan masyarakat melakukan penelitian ilmiah sebagai upaya evaluasi dari keadaan lingkungan. Poin keempat, Pemerintah telah mengeluarkan beberapa kebijakan berdasarkan analisis dampak lingkungan, akan tetapi memang pada pelaksanaannya tidak begitu berjalan lancar, seperti kebijakan plastik berbayar. Dan pada poin kelima, penulis melihat sampah di Kota Tangsel belum dikelola secara maximal untuk menghasilkan nilai, seperti kerajinan yang memiliki nilai ekonomi.

Berdasarkan analisis dari peran Pemerintah dan masyarakat yang telah dilakukan tersebut, menjadi sebuah gerakan zero waste atau pengurangan nol sampah di Kota Tangsel. Selain itu juga hal tersebut dijadikan sebagai politik lingkungan untuk melakukan kebijakan dan program yang berorientasi pada kepentingan dalam keberlangsungan lingkungan hidup di Kota Tangsel. Tentu tindakan tersebut menjadi sebuah gerakan sosial, karena masyarakat yang terlibat pun bersifat sukarela dan dengan keinginan dirinya sendiri.

\section{Upaya dan Solusi Dalam Mengatasi Permasalahan Sampah Di Kota Tangerang Selatan}

Gerakan Zero Waste hadir karena permasalahan sampah di Kota Tangerang Selatan yang jumlahnya semakin menumpuk, hal tersebut diakibatkan seiring dengan 
berjalannya pembangunan di Tangerang selatan. Oleh karena itu, produksi dan konsumsi sampah terus meningkat serta minimnya lahan sebagai tempat pembuangan atau pengelolaan sampah. Konsep zero waste ini menjadi langkah awal sebagai gerakan lingkungan di Kota Tangerang Selatan dengan membentuk berbagai komunitas penggerak lingkungan yang bekerjasama dengan instansi terkait sebagai sebuah solusi yang ditawarkan dan langkah awal untuk menangani persoalan sampah di Kota Tangerang Selatan. Kerjasama yang terjalin tersebut diaharap mampu menjawab dan menyelesaikan permasalahan sampah di Kota Tengerang Selatan. Melihat suatu jumlah penduduk yang besar dan cukup padat, namun lahan yang ada di Kota Tangerang Selatan semakin sedikit mengakibatkan ketersedian lahan semakin terbatas, termasuk juga lahan untuk TPA yang berada di Kota Tangerang Selatan. TPA Cipeucang hanya mampu menampung 30\% dari jumlah keseluruhan produksi sampah perharinya. Kemudian, saat ini berbagai pihak terlalu fokus untuk menangani sampah di belakang yang sudah menumpuk, artinya ketika sudah ada sampah barulah dicarikan solusi bagaimana caranya untuk mengatasi sampah-sampah yang sudah ada tersebut, tanpa memikirkan bagaimana caranya untuk mengurangi produksi sampah dari depan. Padahal, hasil eksperimen LabTanya menyimpulkan bahwa solusi mengurangi sampah yang paling efektif yaitu dengan melakukan reduce atau mengurangi sampah dari depan (mengurangi segala sesuatu yang akan mengakibatkan sampah). Hal tersebut juga yang menyulitkan Pemerintah Daerah untuk memberikan pelayanan dan menyulitkan masyarakat untuk terus mengurangi sampah. Untuk itu beberapa solusi dan saran yang dapat ditawarkan dalam pengelolaan sampah di Tangerang Selatan dalam rangka mendukung gerakan zero waste diperlukan kontribusi aktif dari seluruh elemen, baik masyarakat, pemerintah dan juga organisasi penggerak lingkungan, kolaborasi tersebut akan memudahkan pemerintah dalam menyusun dan menetapkan kebijakan serta memudahkan masyarakat sipil untuk mengurangi sampah dan sama-sama mendukung gerakan zero waste. Adapun yang harus dilakukan oleh ketiga elemen tersebut, diantaranya:

A. Masyarakat, dalam hal ini peran masyarakat menjadi bagian terpenting karena menjadi masyarakat berarti perlu untuk menanamkan sikap empati sesama makhluk hidup. Kepekaan yang tinggi dan pola pikir yang terbuka terhadap permasalahan lingkungan akan membawa masyarakat ke dalam aksi yang positif. Langkahlangkah yang harus dilakukan oleh masyarakat di antaranya : 1) Masyarakat diharuskan untuk dapat memilah berbagai sampah yang sejenis, seperti sampah yang dapat terurai dengan mudah, sampah yang memiliki sebuah kandungan zat berbahaya, sampah yang diperoleh akan di daur ulang kembali, dan lainnya. 2) Memikirkan tindakan konsumsi dan produksi sampah, agar permasalahan sampah dapat ditangani dari depan tidak dari belakang. Artinya, masyarakat harus mampu meminimalisir daya beli yang akan berpotensi menjadi sampah. 3) Mengelola sisasisa yang berasal dari sampah kering lalu memiliki nilai ekonomi untuk hasil kreatif melalui Bank Sampah yang telah tersedia di Kota Tangerang Selatan, dan sampah 
organik bisa diolah menjadi kompos. 4) Melibatkan diri dengan komunitas penggerak lingkungan dengan menjadi pelopor.

B. Organisasi Penggerak Lingkungan, dalam hal ini peran organisasi penggerakan lingkungan juga penting karena sebagai wadah yang mengakomodasi aktivitas dan gerakan-gerakan peduli lingkungan baik dari masyarakat ataupun organisasi lainnya yang mempunyai tujuan yang sama. Berbagai cara yang harus dilakukan oleh organisasi penggerak lingkungan di antaranya : 1) Membangun semangat zero waste action yang di mana berarti organisasi-organisasi yang memilih basis gerak pada bidang lingkungan serta menjadi pelopor dan wadah untuk mengurusi persoalan sampah di Kota Tangerang Selatan dengan aksi nyata dan berdasar pada prinsip zero waste. 2) Menjadi front liner dalam memberdayakan masyarakat dan menyampaikan informasi mengenai gerakan lingkungan. 3) Aktif melakukan gerakan peduli lingkungan baik secara ofline maupun online. 4) Menggagas ide-ide kreatif untuk membantu mengurangi permasalah sampah secara masif dan memperluas jaringan dengan organisasi luar daerah, pemerintah, serta pihak lainnya. 5) Melakukan audiensi dengan beberapa pihak dan pemerintah daerah untuk mendapatkan support agar program-program minim sampah dapat terus dilakukan.

C. Pemerintah, dalam hal ini peran pemerintah sebagai pembuat kebijakan dan juga fasilitator tidak bisa dielakkan karena pemerintah berkewajiban untuk memutuskan segala bentuk kebijakan yang menyangkut dengan kenyaman dan kesejahteraan warganya. Dalam rangka mewujudkan zero waste, pemerintah perlu partisipasi dan kontribusi aktif dari masyarakat sipil guna dilibatkan ke dalam pengambilan keputusan. Berbagai upaya yang harus dilakukan oleh pemerintah di antaranya : 1) Pemerintah wajib menyediakan fasilitas pengumpulan sampah yang telah dipilah oleh masyarakat, seperti TPS atau TPS3R. 2) Bekerjasama dengan masyarakat dan juga penggerak lingkungan untuk sama-sama menangani permasalahan sampah tersebut. Program rumah minim sampah sdang dirancang dan akan dimasukkan ke dalam program unggulan DLH Kota Tangerang Selatan, berkolaborasi dengan LabTanya sebagai penggagas. 3) Mengkaji ulang pengelolaan sampah dengan memerhatikan standar teknis dan merancang upaya lain untuk beberapa tahun ke depan dengan memanfaatkan teknologi. Di mana sampah di TPS akan ditransformasikan ke TPA, lalu di TPA sampah akan kelola dengan proses pengelolaan menggunakan teknologi untuk menghasilkan energi listrik dan dapat mengurangi volume sampah mencapai 90\%. Sehingga, konsep zero waste levelnya akan lebih tinggi lagi menjadi waste to energy.

\section{Kesimpulan}

Berdasarkan uraian-uraian diatas terkait gerakan zero waste menjadi sebuah solusi pada konsep serta pola hidup yang berkembang yang termasuk di Daerah Kota Tangerang Selatan. Terdapat prinsip 3R diantaranya reuse, reduce, recycle yang dimana dapat menjadi alternatif dalam menjaga lingkungan hidup. Sebagaimana diketahui 
bahwa persoalan sampah menjadi perhatian sesama untuk ditangani, sehingga pihak Pemerintah, swasta, dan masyarakat menjadi aktor penting yang bersatu dalam menggerakan pola serta gaya hidup minimal waste. Dengan dibuktikan adanya program Rumah Minim Sampah menjadi sebuah inovasi untuk membangunkan kesadaran seluruh pihak agar terus ramah dengan lingkungan. Output dari program tersebut membuktikan dapat mengurangi sebagian sampah yang akan dikirim ke TPA.

Slogan "Kota Tanpa Sampah" menjadi salah satu inisiatif yang berasal dari salah satu komunitas LabTanya yang dapat membentuk atau mendesain terkait kondisi sosial maupun ekologis dalam menghadapi tantangan kehidupan berkota demi mewujudkan Kota yang lestari. Maka kegiatan yang dijalankan dari program tersebut ternilai efektif dan dapat membentuk sebuah karakter serta kreativitas yang dapat memberikan dampak positif bagi seluruh pihak dalam mengelola sumber daya yang tersedia di dalam kegiatan produksi maupun konsumsinya.

\section{Tentang Penulis}

Dewi Rahayu merupakan mahasiswa Ilmu Pemerintahan Fakultas Ilmu Sosial dan Ilmu Politik Universitas Sultan Ageng Tirtayasa. Melihat keadaan pada isu-isu lingkungan yang berkembang, sehingga penulis tertarik dengan kajian politik lingkungan lebih dalam.

Abdul Riyansah merupakan mahasiswa Ilmu Pemerintahan Fakultas Ilmu Sosial dan Ilmu Politik Universitas Sultan Ageng Tirtayasa. Politik lingkungan melalui gerakan zero waste merupakan hal yang penting untuk dilakukan Pemerintah dan masyarakat dalam melakukan suatu perubahan melalui kebijakan lingkungan.

Dewi Sri Astuti merupakan mahasiswa Ilmu Pemerintahan Fakultas Ilmu Sosial dan Ilmu Politik Universitas Sultan Ageng Tirtayasa. Kerusakan lingkungan akan berpengaruh bagi tumbuh kembang makhluk hidup dan ekosistem yang ada di bumi. Solusi yang ditawarkan diharap mampu untuk menjaga kelestarian lingkungan dan keseimbangan ekositem.

Faidurrizal merupakan mahasiswa Ilmu Pemerintahan Fakultas Ilmu Sosial dan Ilmu Politik Universitas Sultan Ageng Tirtayasa. Zero waste merupakah sebuah konsep yang ditawarkan untuk mengubah pola dan gaya hidup dengan bijak dalam mendukung pengurangan jumlah sampah yang tentu juga dapat menyelamatkan lingkungan.

\section{Ucapan Terimakasih}

Penulis mengucapkan banyak terima kasih kepada pihak-pihak yang telah terlibat dan membantu penelitian ini sampai dengan selesai, serta M. Dian Hikmawan, M.A yang telah memberikan suatu pembelajaran yang sangat bermakna serta bermanfaat, sehingga layak untuk dipublikasikan. 


\section{Referensi}

Bappeda Kota Tangerang Selatan. Rencana Pembangunan Jangka Menengah Daerah Kota $\begin{array}{lll}\text { Tangerang Selatan 2016-2021. } & \end{array}$ https:// bappeda.tangerangselatankota.go.id/uploads/perwal/7.pdf.

Gerakan Indonesia Diet Kantong Plastik. (2017). Zero Waste: Solusi Menyelesaikan Permasalahan Sampah Plastik. https://dietkantongplastik.info/zero-waste-solusimenyelesaikan-permasalahan-sampah-plastik/

Hidayat, H. (2011). Politik Lingkungan Pengelolaan Hutan Masa Orde Baru Dan Reformasi. Jakarta: Pustaka Obor Indonesia.

Islamy, La Ode Syaiful. (2018). Collaborative Governance: Konsep dan Aplikasi. Yogyakarta: CV. Budi Utama.

Kementrian Lingkungan Hidup dan Kehutanan. (2015). Penanganan Sampah Di Kota Tangerang Selatan. Kanal Komunikasi. http:/ / kanalkomunikasi.pskl.menlhk.go.id/penanganan-sampah-di-kotatangerang-selatan/Kraft, M. E. (2011). Environmental Policy And Politics. Boston: Longman.

Moleong, L. J. (2011). Metode Penelitian Kualitatif. Bandung: Remaja Rosdakarya.

Pahrudin, L. (2021, Februari 12). Ekspor Sampah Tangsel Ke Serang, Truth: Siapa Untung? Retrieved from https://www.rmolbanten.com/read/2021/02/12/21661/Ekspor-SampahTangsel-Ke-Serang,-Truth:-Siapa-Untung

Saribanon, N., Soetarto, E., Sutjahjo, S. H., Sa'id, E. G., \& Sumardjo. (2009). Perencanaan Sosial Dalam Pengelolaan Sampah Permukiman Berbasis Masyarakat Di Kota Madya Jakarta Timur. Jurnal Forum Pascasarjana, 145-154.

Sugiyono. (2012). Metode Penelitian Kombinasi (Mixed Methods). Bandung: Alfabeta.

Sukmana, O. (2016). Konsep dan Teori Gerakan Sosial. Malang: Intrans Publishing.

Wawancara langsung Tim Peneliti dengan Yepi. Dinas Lingkungan Hidup, Kota Tangerang Selatan. Mei 2021.

Wawancara online Tim Peneliti dengan Wilma. Google Meet. Juni 2021. 